\section{Narkolepsieregister, deutsches}

Helga Peter

Marburg, Deutschland

\section{Englischer Begriff}

German Narcolepsy Registry

\section{Definition}

An der Hephataklinik in Schwalmstadt implementiertes und seit 2003 prospektiv geführtes Register zur systematischen Erfassung der Daten von Patienten mit $\triangleright$ „Narkolepsie“. 